\section{Influence of Tranquillizing Drugs on Phagocytosis in vivo}

Phagocytosis of invading micro-organisms has long been known to play a major part in the dofence of the mammalian organism against infectious disease. In view of the widespread use and potent pharmacological activity of the tranquillizing drugs, it is not surprising that administration of such compounds has occasionally been associated with alterations in normal resistance to infection ${ }^{1,2}$, and that such altered clinical responses have been linked to changes in the phagocytic activity of the reticuloendothelial system ${ }^{3}$.

Vinegar and Berger ${ }^{4}$ have recently roported that, in high doses, chlorpromazine, hydroxyzine and reserpine slowed the clearance of carbon particles from the blood of mice, but did not do so in low doses. Carbon particle clearance was not altered by meprobamate in either high or low doses. On the other hand, at the low dose employed by Vinegar and Berger, Ludány ${ }^{5,6}$ found marked inhibition by chlorpromazine of the phagocytic activity of leucocytes from peripheral blood of dogs and rabbits.

In an effort to approximate more closely natural conditions than either carbon clearance or in vitro phagocytosis, an in vivo bacterial study was undertaken. Large male Wistar rats in groups of four were injected intraperitoneally with tranquillizing agents suspended in 5 per cent acacia solution. Three doses, $8 \mathrm{hr}$. apart, were administered to the experimental animals while control animals received 5 per cent acacia solution on the same schedule. All food was withheld during the experiment since it has been reported that phagocytic activity is enhanced by starvation?

Eight hours after the last injection of tranquillizer or acacia solution, each animal received $20 \mathrm{ml}$. intraperitoneally of broth culture of Staphylococcus aureus filtered through sterile glass wool and diluted with sterile saline to give approximately 50 per cent transmittance on a Coleman 'Junior' spectrophotometer. After $3 \mathrm{hr}$., animals were killed by decapitation and the peritoneal cavity opened. Duplicate slides of the contents were prepared, stained and counted for phagocytic activity by the method of Kuna et al.?

Table 1. Effect of Pretreatanent with Tranquicr.zens on the

\begin{tabular}{|c|c|c|c|c|}
\hline Drug & $\underset{\underset{\text { kgm.) }}{\text { Dose }}}{\text { mgm./ }}$ & $\begin{array}{c}\text { Percentage } \\
\text { of cells } \\
\text { showing } \\
\text { phagocytosis }\end{array}$ & $\begin{array}{c}\text { Mean } \\
\text { (per cent } \\
S . E .)\end{array}$ & $\begin{array}{c}\text { Signiflcance } \\
\text { of difference } \\
\text { from control } \\
\text { ( } t \text { test) }\end{array}$ \\
\hline $\begin{array}{l}5 \text { per cent } \\
\text { acacia (control) }\end{array}$ & $\cdots$ & $\begin{array}{l}32 \\
38 \\
24 \\
31\end{array}$ & $31 \pm 3$ & - \\
\hline Chlorpromazine & 25 & $\begin{array}{l}63 \\
71 \\
86 \\
70\end{array}$ & $73 \pm 8$ & $P<0.01$ \\
\hline Reserpine & 1 & $\begin{array}{l}20 \\
17 \\
27 \\
25\end{array}$ & $22 \pm 2$ & $P<0.05$ \\
\hline Meprobamate & 200 & $\begin{array}{l}40 \\
63 \\
64 \\
30\end{array}$ & 49 上 8 & $P>0.05$ \\
\hline Hydroxyzine & 25 & $\begin{array}{l}30 \\
31 \\
22 \\
36\end{array}$ & $30 \pm 3$ & $P>0.7$ \\
\hline
\end{tabular}

Table 1 shows the effects of the four test agents on phagocytic activity as compared to acacia controls in a single run. It is apparent that pretreatment of rats with tranquillizing drugs resulted in marked alterations in phagocytic activity, with reserpine significantly depressing phagocytosis, chlorpromazino significantly enhancing phagocytosis, and hydroxyzine and meprobamate being largely without offect in this regard.

Analysis of variance ${ }^{8}$ of the data obtained confirms the fact that the variation in phagocytic activity following drug treatment does not represent variation within a single population.

Repetition of the experiment at later dates gave comparable results, and the control values obtained by us are in agreement with reported values for untreated, starved rats?

Leo Girennberc James W. Ingalis

Research Institute,

Brooklyn College of Pharmacy,

Long Island University, Brooklyn 16, New York.

${ }^{1}$ Kline, N. S., Barsa, J., and Gosline, F., Dis. Ner. Syst., 17, 352 Wardell,

, D. W., Amer. J. Psychiat., 185, 235 (1956).

Meier. R. M., Boroff, D. A., and Heller, J. H., Fed. Proc., 16, 425 (1957).

- Vinegar, R., and lerger, F. M., Proc. Soc. Exp. Biol. Med., 102, 88 (1959). s Ludány, G., Vajda, G., Döklen, A., and Li-Bok-Nam, Orvosi Hetilap.
$\mathbf{9 6 , 1} 100$ (1955). - Ludány, G., Vajda, G., Döklen, A., and Li-Bok-Nam, Schweiz. Med.
Wochen., 86, 1075 (1956).

"Kuna, A., Blattberg, B., and Reiman, J., Proc. Soc. Exp. Biol. Med., $77,510(195 \mathrm{l})$.

Dixon, Wilfred J., and Massey, jun., Frank J., "Introduction to Statistical Analysis", second ed. (McGraw-Hill look Co., Inc.,
New York, 1957).

\section{Influence of the Surface of the Small Intestine on Enzymatic Hydrolysis of Starch by Enzymes}

THE classical conception of digestion as being the sum of processes occurring in the chyme under the influence of hydrolytic enzymes fails to explain many important physiological and clinical phenomena.

In previous papers ${ }^{1,2}$ it was shown that cavital (chyme) digestion is probably not the sole or main mechanism underlying the hydrolysis of food. It was suggested that the surface of the intestine presents a living porous reactor (the pores being formed by microvilli), on the surface of which intensive hydrolysis occurs on account of enzymes (self-contained and adsorbed) on the external side of the cellular membrane. (The presence of microvilli was first demonstrated by Granger and Baker ${ }^{3}$ and later confirmed by many authors.)

The enzymes form a rather strong layer, which possibly has an ultrastructure analogous to what is known about enzymes on the membrane of mitochondria.

This is of great importance and suggests an enzymatic conveyer ensuring continued splitting followed by absorption of the food.

The system of processes occurring on the surface of the intestine we have designated as membrane or contact digestion ${ }^{1}$. 